\title{
Use of cabbage leaves (Brassica oleracea var. acephala) in the stabilization of bone mass after menopause
}

\author{
João V. Pereira, Hosana B. Santos, Maria F. Agra, Diego N. Guedes, João Modesto-Filho* \\ Laboratório de Tecnologia Farmacêutica, Universidade Federal da Paraíba, Caixa Postal 5009, 58051-970, João \\ Pessoa, PB, Brazil
}

\begin{abstract}
RESUMO: "Uso do suco das folhas da couve (Brassica oleracea var acephala), na estabilização da massa óssea pós-menopausa". Neste trabalho foi avaliado a utilização da folha da couve Brassica oleracea variedade acephala, pertencente à família Cruciferae, para estabilizar a massa óssea em 13 mulheres após a menopausa. As folhas da couve foram usadas após retirar a nervura principal e o peciolo, na forma de suco de uma folha ao dia, durante 24 meses. Foi realizado a cada seis meses o exame de densitometria óssea para avaliar os resultados. Os locais de medição foram o trocanter e o triângulo de Ward. De acordo com os resultados encontrados, podemos concluir que o uso da folha da couve foi capaz de estabilizar a massa óssea nos sítios estudados, com perspectivas do seu uso também como opção importante para prevenção da doença.
\end{abstract}

Unitermos: Brassica oleracea var. acephala, Cruciferae, couve, osteoporose, menopausa.

\begin{abstract}
This work evaluates the use of cabbage leaves, Brassica oleracea var acephala (Cruciferae family) to stabilize bone mass in 13 menopausal women. The mature leaves were used after removal of the midrib and petiole and taken as a juice and given to the patient once a day for 24 months. Densitometric exams were performed every six months. The measurement points were the Trocanter and Ward's triangle. According to the results found, the use of cabbage leaf juice results in bone mass stabilization at the points studied, with perspectives for its use as an important option in disease prevention.
\end{abstract}

Keywords: Brassica oleracea var. acephala, Cruciferae, cabbage, osteoporosis, menopause.

\section{INTRODUCTION}

At present, the need to know and prevent aging related diseases in the population is a factor which receives much attention all over the world. The researchers and health sectors concern is to understand and resolve in a definitive or preventive way the several diseases that accumulate specially after the age of 40. Among those diseases, osteoporosis has stood out because it is a chronic, multifactorial disease which occurs in both sexes, albeit more common in women after menopause. It is characterized by the progressive loss of bone mass and the deterioration of bone tissue microarchitecture, which becomes more susceptible to fractures (Wilson; Foster, 1988; Compston, 1990). In Brazil in the 90's, women represented $55 \%$ of the population over 60 . Taking into account that the risk of vertebrae and hip fractures in white menopausal women is around $15-17 \%$, it can be concluded that at least one third of them will suffer osteporotic fracture (Melton; Altkorn, 1991). The use of modern techniques such as bone densitometry has made the diagnosis and prevention of this disease possible. However, the high cost of this exam excludes its use for the majority of the population (Pereira et. al., 2002).

It is possible to prevent osteoporosis with the use of physical exercises, hormone reposition therapy, and calcium-rich diet. It is also necessary to change habits which may somehow interfere in the absorption and the permanence of calcium in the organism such as tabagism (Griffin, 1990; Seeman; Tsalamandris, 1994; McCulloch et al., 1990; Slemenda et al., 1992); alcohol (Sowers; Galuska, 1993), and caffeine (Tassinari et al., 1991) consumption.

At present, several therapies are used to treat osteoporosis, they include: hormone reposition therapy (Felson; Zhang, 1993; Lindsay; Hart, 1976), calcium and vitamin D supplementation (Riis, 1987; Resnick; Greenispan, 1989; Chapuy; Arlot, 1992; Tilyard; Spears, 1992), tibolone (Belchetz, 1994), calcitonin (Correia, 1992; Reginster, 1992) and bisfosfonate (Rigss; Melton III, 1992). However, these therapies cannot recuperate significantly bone mass lost after menopause, and in many cases they result only in its stabilization.

Despite all developments, the number of medicinal plants studied from the chemical and pharmacological viewpoint is very small, and even in developed countries their use is related to the application of active principles, making the research of this untapped field attractive in current research (Pereira et al., 2002; Silva et al., 2003; Rocha et al., 2005; Falcão et al., 2005; 
Barbosa-Filho et al., 2005; Barbosa-Filho et al., 2006a,b). Use of ethnopharmacological knowledge is one attractive way to reduce empiricism and enhance the probability of success in new drug-finding efforts (Patwardhan, 2005; Cordell; Colvard, 2005). The use of cabbage (Brassica oleracea var acephala) in popular medicine has been passed on from generation to generation with very interesting reports of improvement and cure of many diseases, such as gastritis, rheumatism, ulcer, bone weakness, vision diseases, hepatic diseases, anemia; while it is much recommended for developing children (Almeida, 1993). As preventive methods are not available to all patients, we aim to evaluate the importance of the use of cabbage leaves in the stabilization of bone mass to make this means of prevention more accessible to the population at large, due especially to its easy access and low cost.

\section{MATERIAL AND METHODS}

The leaves of cabbage (Brassica oleracea var. acephala) were collected in the city of João Pessoa, Paraíba, Brazil in April 2004. A voucher specimen (Agra et al. 5960) is kept at the herbarium Prof. Lauro Pires Xavier, João Pessoa, Paraíba, Brazil.

Mature cabbage leaves weighing approximately $20 \mathrm{~g}$ were used after removal of the midrib, cutting them in small pieces and blending them with $400 \mathrm{~mL}$ water. This juice was taken between meals once a day.

The study was carried out with 13 menopausal women with osteoporosis with an average age of 58.5 who took cabbage leaf juice once a day for 24 months. Bone densitometry was carried out at 0 , six, twelve, eighteen and twenty-four months.

Bone mass was determined using bone densitometry. Exams were carried out with DEXA densitometry using gandolin 153 for photonic emission with values between 44 and $100 \mathrm{KeV}$.

Statistical analysis. Bone mineral density (BMD) results in $\mathrm{g} / \mathrm{cm}^{2}$ on Ward's triangle and Trocanter in menopausal patients were submitted to variance analysis for an entirely randomized delineation using the $F$ test to compare the average square of exam time with the quantity of cabbage leaves, according to PimentelGomes (1985). The comparison of average exam times with the quantity of cabbage leaves was preceded by the Tukey test at the 5\% probability level (Steel; Torrie, 1960; Pimentel-Gomes, 1985). For the statistical analysis, the software Statistical Analysis Symidrib (SAS), described by SAS Institutue (1997) was used.

\section{RESULTS}

Table 1 shows the variance analysis of bone mineral density (BMD) in $\mathrm{g} / \mathrm{cm}^{2}$ in the Ward's triangle and the Trocanter in menopausal patients. The results did not show a significant difference. The results given in Table
2 for the average values of BMD in the Ward's triangle and the Trocanter did not present a statistically significant difference either. Table 3 displays the values found for T-score and Z-score in relation to the time. Their results did not vary with statistic significance. BMD values as a function of exam time for the Ward's triangle and the Trocanter are displayed in Figures 1 and 2, respectively. These results did not present a statistically significant difference.

\section{DISCUSSION}

In our experiments the botanical material was prepared as it is used popularly, cabbage leaf juice, fresh, after the removal of the midrib. At present the consensus is that the possibility of occurrence of fractures increases directly with the decrease in bone mass. The risk increases between 1.5 to 2.5 times for each decrease of 1 standard deviation, doubling for losses higher than 10\% (Cummings et al., 1993). Current epidemiological studies tend to define fracture risk in any part of the skeleton by means of a single measure, thus, for example, for the femur fracture risk it is necessary to evaluate the bone mineral density at this site (Grinley et al., 1979). The densitometric measurements carried out in the Trocanter and the Ward's triangle are important to detect bone mineral density loss in the proximal femur, being also indicated for monitoring osteoporosis treatment (Johnston et al., 1991). The evaluation criteria used in this study agree with the operational definition to measure bone mass described by Mazaes (1987). As shown in Table 1, the variance analysis of bone mineral density (BMD) in Ward's triangle and Trocanter did not present any significant difference $(\mathrm{P}>0.05)$ in the bone mineral density in relation to time, showing that the use of cabbage leaf juice in stabilizing bone mass was successful in the time frame studied. The analysis of the average values of bone mineral density in Ward's triangle and the Trocanter in relation to time (Table 2) revealed no significant difference in BMD $(\mathrm{P}>0.05)$ between examination times. There is no statistically significant difference in relation to T-score and Z-score for the times analyzed, as shown in Table 3 . These results indicate that the variation in bone mineral density in the period of 24 months was not statistically significant. As shown in Figure 1, in relation to Ward's triangle, there was a rapid increase in BMD in the first six months, later decreasing within a period of twenty-four months, however the variations are not statistically significant $(\mathrm{P}>0.05)$, likewise for the Trocanter, as shown in Figure 2. These results show that the therapy with cabbage leaf juice successfully inhibited bone mass loss in Ward's triangle and the Trocanter in the time frame studied; similar results are described in relation to calcium supplementation, which is only able to stabilize bone mass (Rigss; Melton III, 1992). However, it is valuable as an adjuvant, potentiating the effects of other therapies (Riis, 1987; Resnick; Greenispan, 1989). 
Table 1. Variance analysis of bone mineral density (BMD) in $\mathrm{g} / \mathrm{cm}^{2}$ in Ward's triangle and Trocanter of menopausal patients.

\begin{tabular}{llll}
\hline Variation Sources & DF & \multicolumn{2}{c}{ Average Squares } \\
\cline { 3 - 4 } & & Ward's triangle & Trocanter \\
\hline Exam Time & 3 & $0.0061025 \mathrm{~ns}$ & $0.0005539 \mathrm{~ns}$ \\
Linear & 1 & $0.0007046 \mathrm{~ns}$ & $0.0011976 \mathrm{~ns}$ \\
Quadratic & 1 & $0.0175757 \mathrm{~ns}$ & $0.0004561 \mathrm{~ns}$ \\
Cubic & 1 & $0.0000271 \mathrm{~ns}$ & $0.0000081 \mathrm{~ns}$ \\
Residue & 48 & 0.0206899 & 0.0117838 \\
\hline VC $(\%)$ & - & 20.39 & 15.30 \\
\hline
\end{tabular}

ns - not significant.

VC (Variation coefficient)

DF (Degree of freedom)

Table 2. Average values of bone mineral density (BMD) in the Ward's triangle and the Trocanter in menopausal patients.

\begin{tabular}{ccc}
\hline $\begin{array}{c}\text { Exam Time } \\
\text { (months) }\end{array}$ & $\begin{array}{c}\text { Ward's triangle } \\
\left(\mathrm{g} / \mathrm{cm}^{2}\right)\end{array}$ & $\begin{array}{c}\text { Trocanter } \\
\left(\mathrm{g} / \mathrm{cm}^{2}\right)\end{array}$ \\
\hline 6 & $0.692 \mathrm{a}$ & $0.713 \mathrm{a}$ \\
12 & $0.726 \mathrm{a}$ & $0.714 \mathrm{a}$ \\
18 & $0.721 \mathrm{a}$ & $0.711 \mathrm{a}$ \\
24 & $0.682 \mathrm{a}$ & $0.700 \mathrm{a}$ \\
\hline General average & 0.705 & 0.710 \\
MSD (Tukey at 5\%) & 0.150 & 0.113 \\
\hline
\end{tabular}

$\mathrm{a}=$ In columns, averages followed by the same letter did not differ significantly from each other by the Tukey test at $5 \%$ probability.

MSD (Minimal significant difference in Tukey at 5\% probability)

Table 3. Values of bone mineral densitometry (BMD) in Ward's triangle and Trocanter of patients examined in relation to T-score and Z-score.

\begin{tabular}{|c|c|c|c|c|}
\hline \multirow{2}{*}{$\begin{array}{c}\text { Time } \\
\text { (months) }\end{array}$} & \multicolumn{2}{|c|}{ Ward's triangle } & \multicolumn{2}{|c|}{ Trocanter } \\
\hline & $\mathrm{T}$ & $\mathrm{Z}$ & $\mathrm{T}$ & Z \\
\hline 6 & 78.50 & 96.10 & 91.90 & 99.80 \\
\hline 12 & 80.60 & 99.90 & 91.90 & 100.00 \\
\hline 18 & 81.30 & 100.40 & 90.90 & 99.00 \\
\hline 24 & 76.90 & 95.60 & 89.30 & 97.50 \\
\hline Average & 79.33 & 98.00 & 91.00 & 99.08 \\
\hline F Test & $0.16 \mathrm{~ns}$ & $0.45 \mathrm{~ns}$ & $0.07 \mathrm{~ns}$ & 0.11 \\
\hline $\mathrm{VC}(\%)$ & 19.95 & 12.01 & 15.99 & 10.72 \\
\hline MSD & 19.07 & 14.18 & 17.53 & 12.80 \\
\hline
\end{tabular}

ns (Not significant)

VC (Variation coefficient)

MSD (Minimal significant difference in Tukey at 5\% probability)

This fact is extremely important, since the medicines presently used for this purpose are rather expensive, which excludes their use by most patients. The use of cabbage leaf juice is of easy access and inexpensive, which makes the implementation of bone mass loss prevention programs in post-menopausal patients simple. In addition, this treatment would probably also be valuable in the prevention of bone mass loss occurring in abnormal levels in this age group.

On the occasion of the densitometry exams every six months, the patients' reports were interesting and significant, calling our attention mainly to the improvement of the gastric (gastritis) and ophthalmologic problems, with the improvement of sight during treatment time. At the end of the study period (twenty-four months), there were reports of reduction of gastric and ophthalmologic problems. This suggests that a better evaluation and study should be made in future research.

\section{CONCLUSION}

The present work shows that the use of cabbage leaf juice once a day led to the stabilization of bone mass in the sites analyzed while it can also be used as a means of prevention either in isolation or as an auxiliary to existing therapy. The easy access to the product at a 


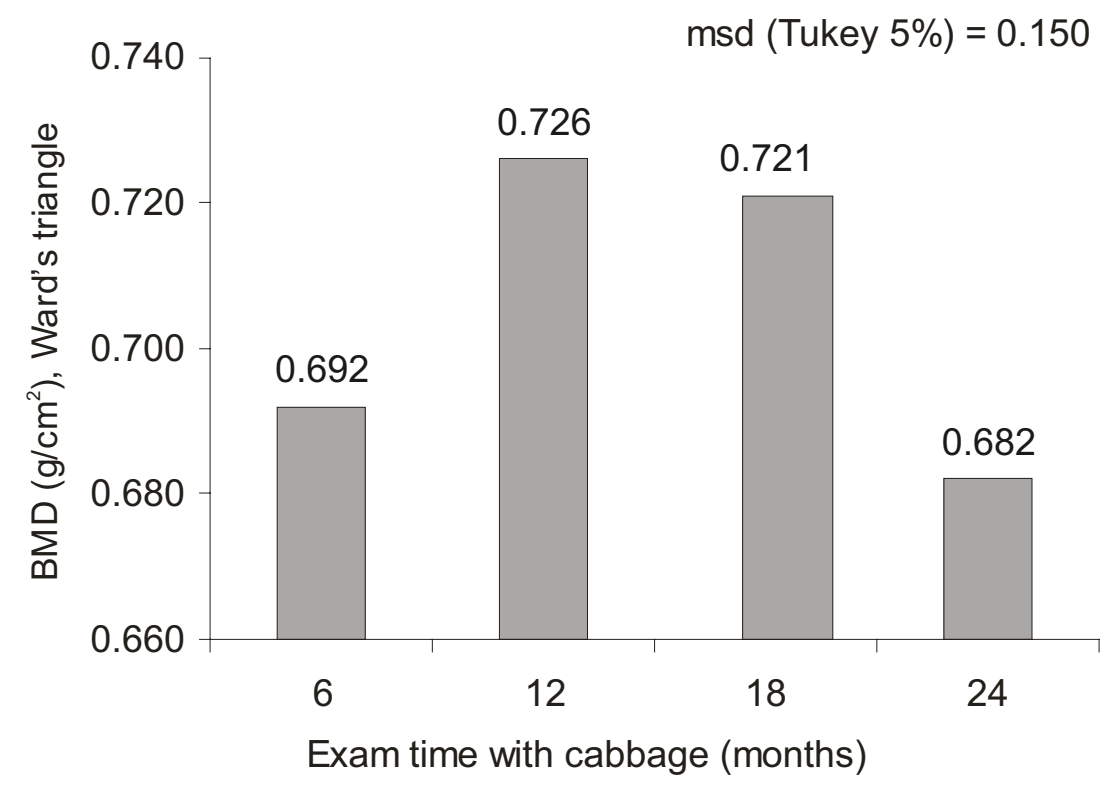

Figure 1. Bone mineral density in Ward's triangle in menopausal patients as a function of exam time with cabbage leave.

msd $($ Tukey $5 \%)=0.113$

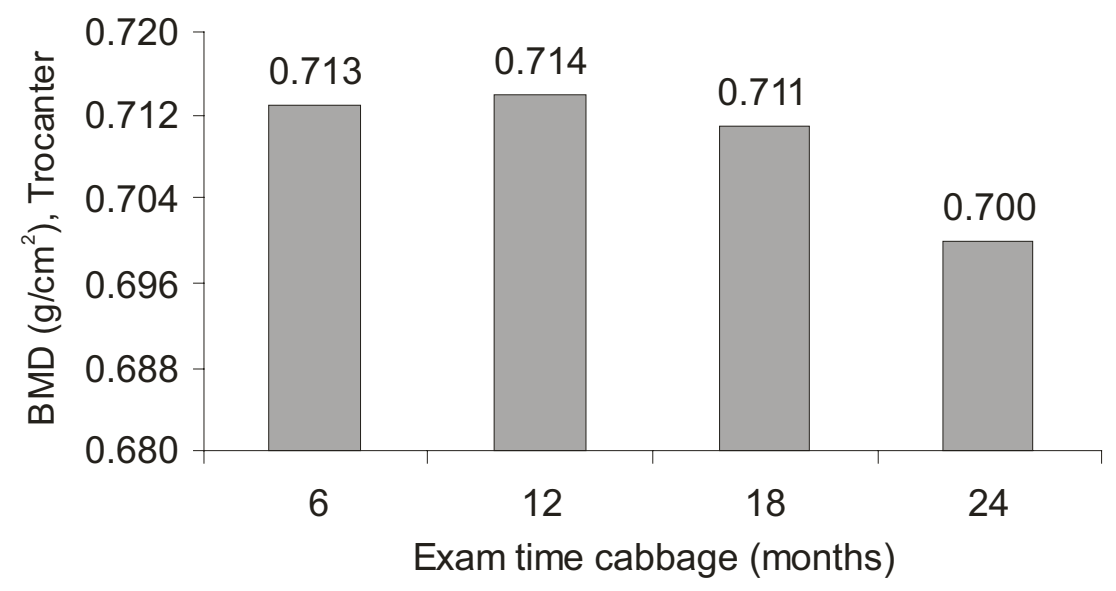

Figure 2. Bone Mineral Density in Trocanter in menopausal patients as a function of exam time with cabbage leave.

practically insignificant cost makes its use possible by underprivileged classes.

\section{ACKNOWLEDGEMENTS}

The authors are grateful to $\mathrm{CNPq} / \mathrm{Brazil}$ for grants and fellowships. Sincere thanks are also due to NAPRALERT database of the University of Illinois Chicago for the bibliographical information of Brassica oleracea species.

\section{REFERENCES}

Almeida ER 1993. As plantas medicinais brasileiras. Hemus, São Paulo, 339 p.

Barbosa-Filho JM, Vasconcelos THC, Alencar AA, Batista LM, Oliveira RAG, Guedes DN, Falcão HS, Moura MD, Diniz MFFM, Modesto-Filho J. 2005. Plants and their active constituents from South, Central, and North America with hypoglycemic activity. Rev Bras Farmacogn 15: 392-413.

Barbosa-Filho JM, Piuvezam MR, Moura MD, Silva MS, Lima KVB, Cunha EVL, Fechine IM, Takemura OS 2006a. Anti-infl ammatory activity of alkaloids: A twenty-century review. Rev Bras Farmacogn 16: 109-139.

Barbosa-Filho JM, Medeiros KCP, Diniz MFFM, Batista LM, 
Athayde-Filho PF, Silva MS, Cunha EVL, Almeida JRGS, Quintans-Júnior LJ 2006b. Natural products inhibitors of the enzyme acetylcholinesterase. Rev Bras Farmacogn 16: 258-285

Belchetz PE 1994. Hormonal treatment of postmenopausal women. New Engl J Med 330: 1062-1071.

Chapuy MC, Arlot ME 1992. Vitamin D3 and calcium to prevent hip fractures in elderly women. New Engl J Med 327: 1637-1641.

Cordell GA, Colvard MD 2005. Some thoughts on the future of ethnopharmacology. J Ethnopharmacol 100: 5-14.

Correia PHS 1992. Avaliação da eficácia da calcitonina sintética de salmão (Spray nasal) em pacientes pósmenopausadas com alta remodelação óssea. $R B M-$ Ginecologia e Obstetrícia 3: 204-228.

Compston JE 1990. Osteoporoses. Clin Endocrinol 33: 653658.

Cummings SR, Black DM, Nevit MC 1993. Bone density at various sites for prediction of hip fractures. The study of osteoporotic fractures research group. Lancet 341: 72-75.

Falcão HS, Lima IO, Santos VL, Dantas HF, Diniz MFFM, Barbosa-Filho JM, Batista LM 2005. Review of the plants with anti-infl ammatory activity studied in Brazil. Rev Bras Farmacogn 15: 381-391.

Felson DT, Zhang Y 1993. The effect of postmenopausal estrogen therapy on bone density elderly women. New Engl J Med 329: 1141-1146.

Griffin J 1990. Osteoporoses and risk of fractures. London, Office Healt Economics, 228 p.

Grinley EJ, Prudhan D, Wandless J 1979. A prospective study of fractured proximal femur incidence and outcome. Public Healt (London) 93: 235-241.

Johnston CC, Slemenda CW, Melton LJ 1991. Clinical use of bone densitometry. New Engl J Med 324: 11051109.

Lindsay R, Hart DM 1976. Long-term prevention of postmenopausal osteoporosis by estrogen. Lancet 1: 1038-1041.

Mazaes RB 1987. Bone density in the diagnosis of osteoporosis: Thresholds and breakpoints. Calcif Tissue Int 41: 117-118.

McCulloch RG, Bailey DA, Huston CS 1990. Effects of physical activity, dietary calcium intake and selected lifestyle factors of bone density in young women. Can Med Assoc J 142: 221-227.

Melton W, Altkorn EJ 1991. Long-term facture risk prediction with bone mineral measurements made at various skeletal sites. J Bone Miner Res 6 (Suppl. 1): S136.

Patwardhan B 2005. Ethnopharmacology and drug discovery. $J$ Ethnopharmacol 100: 50-52.

Pereira JV, Modesto-Filho J, Agra MF, Barbosa-Filho JM 2002 Plant and plant-derived compounds employed in prevention of the osteoporosis. Acta Farm Bonaerense 21: 223-234.

Pimentel-Gomes F 1985. Curso de estatística experimental. 11a. Ed., São Paulo, Nobel, 466 p.

Resnick NM, Greenispan SL 1989. Senile osteoporosis reconsidered. JAMA 261: 1025-1029.

Reginster JY 1992. Management of high turnover osteoporosis with calcitonin. Bone 13(Suppl. 2): S37-S40.

Rigss BL, Melton III LJ 1992. The prevention and treatment of osteoporosis. New Engl J Med 327: 620-628.
Riis B 1987. Does calcium supplementation prevent postmenopausal bone loss? New Engl J Med 316: 173-177.

Rocha LG, Almeida JRGS, Macedo RO, Barbosa-Filho JM 2005. A review of natural products with antileishmanial activity. Phytomedicine 12: 514535.

SAS Institute 1997. User's guide: statistics. Version 6.12 CDROM, Cary USA, North Carolina State University.

Seeman E, Tsalamandris C 1994. Reduced femoral neck bone density in the daughters of woman with hip fractures: the role of low peak bone density in the pathogenesis of osteoporosis. $J$ Bone Miner Res 9 : 739-745.

Silva JS, Moura MD, Oliveira RAG, Diniz MFFM, BarbosaFilho JM 2003. Natural products inhibitors of ovarian neoplasia. Phytomedicine 10: 221-232.

Slemenda CW, Christian JC, Reed T 1992. Long-term bone loss in men: Effect of emetic and environmental factors. Ann Intern Med 117: 286-291.

Sowers MFR, Galuska DA 1993. Epidemiology of bone mass in premenopausal women. Epidemiol Rev 15: 374398.

Steel RGD, Torrie JH 1960. Principles and procedures of statistics. New York, McGraw-Hill, $481 \mathrm{p}$

Tassinari MS, Gerstenfeld LC, Stein GS 1991. Effect of caffeine on parameters of osteoblast growth and differentiation of a mineralized extracelular matrix in vivo. J Bone Miner Res 6: 1029-1036.

Tilyard MW, Spears GFS 1992. Treatment of postmenopausal osteoporosis with calcitrol or calcium. New Engl J Med 326: 357-362.

Wilson JD, Foster DW 1988. Tratado de Endocrinologia, 7a Ed., São Paulo, Manole. 